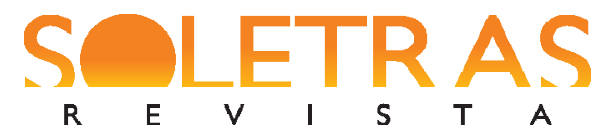

\section{Narcisa Amália, poeta esquecida do século XIX}

Anna Faedrich ${ }^{1}$

Resumo: Analiso a importância da produção poética de Narcisa Amália (1852-1924)no cenário literário brasileiro do século XIX e os mecanismos de exclusão das escritoras brasileiras de nossos registros literários. Ignoramos a literatura de autoria feminina do século XIX, não por falta de escritoras ou publicações de mulheres, mas por deliberado alijamento delas da história literária. O mundo das nossas letras é predominantemente masculino. Intenciono mostrar como Narcisa Amália conquistou espaço neste universo restrito aos homens, sua consciência sobre a opressão sofrida por ser mulher e a recepção crítica de sua obra.

Palavras-chave: Narcisa Amália. Nebulosas. História da Literatura Brasileira. Crítica Literária. Século XIX.

\title{
Introdução
}

Este texto é um recorte dos resultados de uma pesquisa mais ampla, sobre escritoras brasileiras oitocentistas e seus repertórios de exclusão da vida e história literárias, que pretende dar conta da análise de parte da literatura de autoria feminina deste período e do estudo sociológico acerca do apagamento contínuo de escritoras da memória literária. Neste trabalho, apresento a poeta fluminense Narcisa Amália, sua obra ï composta de poemas, cartas e artigos publicados na imprensa periódica ï e a sua repercussão estrondosa à época. Proponho reflexões sobre o modo como Narcisa conseguiu inserção no espaço literário interdito às mulheres, a hostilidade de uma crítica que desqualifica $і ̈$ de forma explícita ou velada, com ou sem razão ï qualquer produção literária escrita por mulheres e as suas consequências.

\section{Narcisa Amália: poeta romântica, poeta esquecida}

Narcisa Amália (1852-1924), importante intelectual brasileira do século XIX, foi poeta romântica $і ̈$ tendo publicado seu único livro de poemas, Nebulosas (1872), aos vinte

\footnotetext{
${ }^{1}$ Anna Faedrich é Doutora em Letras (PUCRS). Professora Adjunta do CAp-UERJ e professora colaboradora do Programa de Pós-Graduação Latu Sensu em Literatura Brasileira (UERJ). Foi Pesquisadora Residente da Fundação Biblioteca Nacional (2014-2015), onde realizou pesquisa sobre escritoras brasileiras do entresséculos (1870-1930). Organizou as reedições do romance Exaltação (1916), de Albertina Bertha, e do livro de poemas Nebulosas (1872), de Narcisa Amália, pela Gradiva Editorial em coedição com a Biblioteca Nacional. anna.faedrich@gmail.com
} 
anos de idade $\ddot{i}$, feminista, republicana, abolicionista, tradutora do francês e jornalista profissional. Iniciou a carreira como tradutora de contos e ensaios de autores franceses, como a escritora George Sand (pseudônimo masculino da autora Amandine Aurore Lucile Dupin, 1804-1876) e o paleobotânico Gaston de Saporta (1823-1895). A reunião desses trabalhos foi seu primeiro livro publicado, o qual expandiu seu sucesso de tradutora. Em sua produção poética, destacam-se a diversidade temática e o domínio da forma, bem como os diálogos com os poetas e escritores do Romantismo. Entre os 44 poemas publicados em Nebulosas e poemas esparsos publicados em jornais, é possível encontrar poemas nacionalistas, políticos, de exaltação da pátria e da natureza, tristes e melancólicos, de saudade da terra e da infância, abolicionistas e antiescravistas. Ademais, foi uma das ñsenhoras colaboradorasò do Almanaque de Lembranças Luso-Brasileiro. Criado por Alexandre Magno de Castilho, em 1851, o Almanaque de Lembranças Luso-Brasileiro teve grande circulação em Portugal e no Brasil. Tratava-se de uma coletânea de textos diversos: anedotas, chistes, logogrifos, poemas, biografias, estudos críticos, receitas, passatempos, charadas etc. Inicialmente, a publicação chamava-se Almanaque de Lembranças; a partir de seu quinto número passou a chamar-se Almanaque de Lembranças Luso-Brasileiro; e, em 1872, Novo Almanaque de Lembranças. ${ }^{2}$ Narcisa Amália contribui com o Novo Almanaque de Lembranças, nos anos 1874, 1888 e 1917.

Nascida em São João da Barra (RJ), a poeta são-joanense teve de se mudar para Resende, aos 11 anos de idade, por conta de uma doença pulmonar do pai. ${ }^{3}$ Narcisa Amália adotou Resende como sua cidade do coração, seu r̃éden de encantosò, enaltecendo-a em poema intitulado ñA Resendeò:

A Resende

Eu te achei, meu bordão de romeiro

Que mal mấsperavas... talvez!

Teixeira de Mello

Enfim te vejo, estrela da alvorada,

Perdida nas celagens do horizonte!

\footnotetext{
${ }^{2}$ As professoras Dr ${ }^{\mathrm{a}}$. Vania Chaves e Dra ${ }^{\mathrm{a}}$. Isabel Lousada, do CLEPUL (Centro de Literaturas e Culturas Lusófonas e Europeias da Faculdade de Letras da Universidade de Lisboa), coordenam o projeto ñSenhoras do Almanaqueò, do qual faço parte, que investiga a participação feminina no Almanaque.

${ }^{3}$ Narcisa Amália nasceu no dia 3 de abril de 1852, e faleceu na cidade do Rio de Janeiro em 24 de julho de 1924. Embora tenha se propagado o dia 24 de junho de 1924 como sua data de falecimento, o mês correto é julho, como atestado por anúncios de falecimento publicados no dia seguinte à morte, em jornais como Correio da Manhã, Jornal do Brasil, O Paiz, A noite e outros.
} 
Enfim te vejo, vaporosa fada,

Dolente presa de um sonhar insonte!

Enfim, de meu peregrinar cansada,

Pouso em teu colo a suarente fronte,

$\mathrm{E}$, contemplando as pétreas cordilheiras,

Ouço o rugir de tuas cachoeiras!

Mal sabes que profundos dissabores

Passei longe de ti, éden de encantos!

Quanto acerbo sofrer, quantos agrores

Umideci coĈs bagas de meus prantos!

Sem um raio sequer de teus fulgores...

Sem ter a quem votar meus pobres cantos...

Ai! O simun cruel da atroz saudade

Matou-me a rubra flor da mocidade!

Vivi bem triste! O coração enfermo

Buscava embriagar-se de harmonias,

Porém via do céu no azul sem termo

Um presságio de novas agonias!...

O bulício do mundo era-me um ermo

Onde as lavas do amor chegavam frias...

Só uma melancólica miragem

Dourava-me a solidão ï a tua imagem! [...] (AMÁLIA, 2017, p. 80).

No célebre poema ñCanção do Exílioò, Gonçalves Dias exilado em Portugal glorifica a pátria amada e distante, mostrando os valores naturais do Brasil, em contraposição aos valores portugueses, e a vontade que tem de voltar à terra natal antes de morrer: ñMinha terra tem palmeiras,/Onde canta o Sabiá./Não permita Deus que eu morra,/Sem que eu volte para lá;/Sem que eu desfrute os primores/Que não encontro por cáò. O poema ñA Resendeò de Narcisa Amália dialoga com a temática da ñCanção do Exílioò, uma vez que o eu lírico deste poema sofre com a distância de sua ñestrelada da alvoradaò, ñvaporosa fadaò, ñéden de encantosò. Longe de Resende, o peregrinar é cansativo, a vida é triste, o coração é enfermo, e a saudade é atroz.

Sylvia Paixão observa que os poemas de Amália ñ̃ão expressivos do Romantismo na exaltação da natureza, nas lembranças da infância e no amor à pátria. Narcisa Amália é, por certo, um dos raros nomes femininos que falam de identidade nacional, através da exaltação da terra brasileiraờ(PAIXÃO, 2000, p. 535). Tal expressão do Romantismo está presente em ñA Resendeò, cujo eu lírico sente-se feliz por retornar à cidade adorada. Desejo este consonante ao do eu lírico de ñCanção do Exílioò, o qual suplica para que não morra sem antes voltar para desfrutar os primores de sua terra. No poema de Amália, a repetição do advérbio de tempo enfim nos primeiro, terceiro e quinto versos reforça o desejo de regresso 
depois de muito tempo longe: ñEnfim, de meu peregrinar cansada,/Pouso em teu colo a suarenta fronte,/E, contemplando as pétreas cordilheiras,/Ouço o rugir de tuas cachoeiras!ò. A intimidade amorosa com a cidade e sua natureza é expressa pelo recurso da personificação utilizado no verso ñpouso em teu colo a suarente fronteò Depois de muita solidão, profundos dissabores, prantos e agonia, o eu lírico consegue, finalmente, descansar em sua terra, o lugar predileto, sob a metáfora do colo que o abriga e ampara.

Também o poema ñSaudadesò evoca a infância, tema comum aos poetas românticos brasileiros, associada à exaltação da natureza:

Tenho saudade dos formosos lares Onde passei minha feliz infância; Dos vales de dulcíssima fragrância, Da fresca sombra dos gentis palmares.

Minha plaga querida! Inda me lembro Quando através das névoas do ocidente $\mathrm{O}$ sol nos acenava adeus languente Nas balsâmicas tardes de Setembro;

Lançava-me correndo na avenida Que a laranjeira enchia de perfumes! Como escutava trêmula os queixumes Das auras na lagoa adormecida!

Eu era de meu pai, pobre poeta, $\mathrm{O}$ astro que o porvir lhe iluminava; De minha mãe, que louca me adorava, Era na vida a rosa predileta!...

Mas... ... tudo se acabou. A trilha olente Não mais percorrerei desses caminhos... Não mais verei os míseros anjinhos Que aqueciam na minha mão algente! [...]

Abrem-me nôlma as dores da saudade Um sulco de profundas agonias...

Morreram-me pôa sempre as alegrias...

Só me resta um consolo... a eternidade! (AMÁLIA, 2017, p. 38-39).

O eu lírico sente saudades do lar onde passou sua infância, rememorando o contato com a natureza ï a fragrância dos vales, a sombra dos palmares, o pôr-do-sol, a lagoa adormecida etc. A saudade é dolorosa, as lágrimas correm (ñCorrei, ó minhas lágrimas sentidas/Do passado no rórido sudário;/Bem longe está o cimo do Calvário/E já as plantas sinto tão 
feridas!ò), as alegrias morreram e a alma do eu lírico está ferida. Outra característica da lírica ultrarromântica é o sofrimento e o encontro de consolo na morte, expressados no último verso do poema. Não é raro, em Nebulosas, o diálogo com a geração do ñmal do séculoò, apresentando características comuns como a evasão da realidade, a morte como única saída para a dor existencial, pessimismo, isolamento e sofrimento.

Faceta merecedora de destaque da poesia de Narcisa Amália é a abolicionista. Poemas como ño Africano e o Poetaò e ñPerfil de escravaò são paradigmáticos. A ñpoeta dos livresò, como ficou conhecida, dialogava com a geração condoeira, sobretudo com Castro Alves, por quem mantinha profunda admiração. Por ocasião da morte do autor de ñO navio negreiroò em 1871, Amália escreve o poema intitulado ñCastro Alvesò lamentando essa grande perda:

Por que convulsa e geme o pátrio solo Dos montes despertando os ecos lúgubres?

Por que emudece o férvido oceano E à terra, erma da luz, chorando atira Mil turbilhões de lágrimas amargos? Por que de sombras tétricas se vela O firmamento azul? Que mágoa imensa Enluta os corações e arranca o pranto?!... $[\ldots]$

Mas... não morreste, não, condor brasíleo Que nunca morrerão teus puros versos! Não, não morreste, que não morrem Goethes, Não morrem Dantes, Lamartines, Tassos, Garretts, Camões, Gonçalves Dias, Miltons, Azevedos e Abreus. Teus belos cantos Cortarão as caligens das idades Como de Homero os divinais poemas!

E lá da eternidade onde repousas Acolhe o canto meu que o pranto orvalha!... (AMÁLIA, 2017, p. 109-111). 


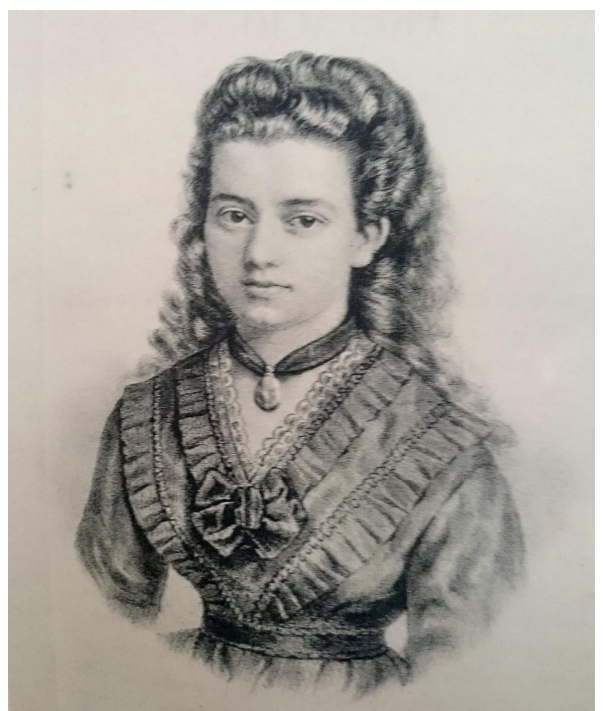

Fig. 1: Narcisa Amália aos 20 anos.

Foto publicada na primeira edição de Nebulosas(1872).

\section{A inserção de Narcisa Amália}

Dado relevante sobre o lançamento de Nebulosas é que o livro foi publicado por uma editora de grande prestígio à época, a Garnier, que patrocinou todos os gastos da impressão. A relevância justifica-se por dois motivos. Primeiro, pelo fato incomum à época de uma mulher publicar um livro.Como afirma Maria de Lourdes Eleutério, ñpara as mulheres da República o sonho de publicar um livro era um projeto distante, a expressão feminina nesse período permanece circunscrita ao espaço privadoò (ELEUTÉRIO, 2005, p. 18). Prova da extraordinariedade do caso é expressa por Machado de Assis no início de sua crônica sobre Nebulosas: ñNão sem receio abro um livro assinado por uma senhoraò (MACHADO DE ASSIS, 1872, s/p). Segundo, pelas condições desfavoráveis de produção intelectual feminina.Araújo observa as dificuldades vivenciadas pelas escritoras em um ambiente hostil e desencorajador:

O cenário excludente agrava-se ao examinarmos a vida literária, que afastava as mulheres dos principais circuitos de legitimação do escritor: editoras pequenas, baixas tiragens, impressões de má qualidade. É eloquente nesse sentido o fato de poucas serem editadas pela Garnier, uma das casas mais renomadas de nossa belle époque (Júlia Lopes de Almeida foi uma das seletas). Dispunham ainda de espaço reduzido nos periódicos, levando-as a criar nichos de publicação feminina, destacando-se A Mensageira ï Revista literária dedicada à mulher brasileira, dirigida por Presciliana Duarte de Almeida. Tampouco se deve esquecer o veto do ingresso feminino na Academia Brasileira de Letras, que só abriu as portas às escritoras 80 anos após sua fundação, com Rachel de Queiroz eleita em 1977 (ARAÚJO, 2014, p. 116). 
Norma Telles analisa o embate desigual de forças na trajetória intelectual da mulher. As chances a favor dos homens acabam dificultando que a mulher ï sujeita à autoridade e à autoria masculina ï perceba e transgrida as prescrições culturais:

Excluídas de uma efetiva participação na sociedade, da possibilidade de ocuparem cargos públicos, de assegurarem dignamente sua própria sobrevivência e até mesmo impedidas do acesso à educação superior, as mulheres no século XIX ficavam trancadas, fechadas dentro de casas ou sobrados, mocambos e senzalas, construídos por pais, maridos, senhores. Além disso, estavam enredadas e constritas pelos enredos da arte e ficção masculina. Tanto na vida quanto na arte, a mulher no século passado aprendia a ser tola, a se adequar a um retrato do qual não era a autora. As representações literárias não são neutras, são encarnações áextuaisô da cultura que as gera. Excluídas do processo de criação cultural, as mulheres estavam sujeitas à autoridade/autoria masculina (TELLES, 2013, p. 408).

Narcisa Amália fez parte do grupo seleto de escritoras que conseguiram se inserir no cenário literário interdito às mulheres, tendo sua obra não apenas publicada em editora renomada, mas também reconhecida por seus pares.A poeta não passou despercebida. Se por um lado a presença encantadora de Narcisa inspirou poetas como Raimundo Correia, ${ }^{4}$ Damasceno Vieira ${ }^{5}$ e Fagundes Varela ${ }^{6}$, sua obra lírica inspirou compositores como Antônio Martiniano da Silva Benfica e João Gomes de Araújo, com as músicas homônimas aos seus poemas ñRecordações do Itatiaiaò e ñO Africano e o Poetaò, respectivamente. Em 30 de janeiro de 1875, o jornal A Reforma publica nota sobre a música composta por Antônio Martiniano da Silva Benfica. Trata-se de uma quadrilha, inspirada pela leitura do poema:

Música ï Recebemos uma quadrilha intitulada Recordações do Itatiaia composta pelo Sr. Antônio Martiniano da Silva Benfica. É uma bela e mimosa composição, que lhe foi inspirada depois da leitura da poesia da nossa festejada poetisa Narcisa Amália, sob mesmo título; nessa composição mostrou o Sr. Benfica mais uma nova fase de seu vasto e cultivado talento.

\footnotetext{
${ }^{4} \mathrm{O}$ ñPoema da noiteò, de Raimundo Correia, foi dedicado a Narcisa Amália. Eis a primeira e a última estrofe: ñTeus cantos o esplendor e a formosura / Da noite exalçam. Lânguido arrepio / Percorre as folhas. Que fragrância pura / Respira em torno o laranjal sombrio! [...] Canta. Eu releio o poema, que tu cantas, / Nessa página azul, que o firmamento / Desdobra, todo em letras de ouro escrito...ò (apud REIS, 1949, p. 167).

${ }^{5}$ Damasceno Vieira publica ñà distinta poetisa fluminense D. Narcisa Amáliaò, na Revista mensal da Sociedade Parthenon Literária, em 1873: ñNão venho coroar-te das grinaldas / Da minha fantasia: audácia fora / Juntar algumas rosas desbotadas / Aos laureis de uma fronte sonhadora. [...] Tu, que as lindas e fúlgidas estrelas / De tuôalma chamaste NEBULOSAS, / Quando elas são no céu da nossa pátria, / Outras tantas estrelas luminosas [...] ò (apud REIS, 1949, p. 169).

${ }^{6} \tilde{n}[. .$.$] Onde hauriste das gregas divindades / O gênio sem rival?!... / Provaste acaso as águas de Castalia, /$ Inspirada e gentil ï Narcisa Amália. / Poetisa imortal?! ’̀, excerto do poema ñTributo de admiração, O Gênio e a Belezaò, dedicado a Narcisa Amália, de Fagundes Varela (apud REIS, 1949, p. 166).
} 
Agradecendo a oferta que nos fez de um exemplar esperamos que continuará a oferecer aos seus numerosos apreciadores novas composições.

Além de o Imperador Dom Pedro II ser seu admirador e fazer questão de conhecê-la pessoalmente em Resende, Machado de Assis escreveu sobre Nebulosas na Semana Illustrada (número 629, 29 dez. 1872):

[...] acaba de publicar a Sra. D. Narcisa Amália, poetisa fluminense, um volume de versos, cuja introdução é devida à pena do distinto escritor de Pessanha Póvoa.[...] não são vulgares as [senhoras] que trazem legítimos talentos, como não são raras as que apenas pagam de uma duvidosa ou aparente disposição, sem nenhum outro dote literário que verdadeiramente as distinga.A leitura das Nebulosas causou-me a este respeito excelente impressão. Achei uma poetisa, dotada de sentimento verdadeiro e real inspiração, a espaços de muito vigor, reinando em todo o livro um ar de sinceridade e modéstia que encanta, e todos estes predicados juntos, e os mais que lhe notar a crítica, é certo que não são comuns a todas as cultoras de poesia. [...] São tristes geralmente os seus versos, quando não são políticos (que também os há bons e de energia não vulgar): a musa da Sra. Narcisa Amália não é alegria; ela mesma o diz na poesia que intitulou ósadnessâ...].

Termino as transcrições e a notícia, recomendando aos leitores as Nebulosas.

Machado de Assis reconhece o valor dos versos de Narcisa Amália, mostrando a distinção de sua obra, que além de causar excelente impressão por seu dote literário, traz bons versos políticos ñde energia não vulgarò. Narcisa Amália impressiona e encanta por assinar um livro $і ̈$ tendo em vista a dificuldade de uma escritora publicar no século XIX ̈̈, por ter legítimo talento e por transgredir as expectativas de uma ñescrita de mulherò, seja pela temática política, seja pelo domínio das técnicas da lírica.

Passo fundamental para a nossa pesquisa é entender os modos de inserção da mulher no sistema literário. Logo no início de sua crônica, Machado de Assis faz menção à introdução de Nebulosas escrita pelo ñdistinto escritorò Pessanha Póvoa (1837-1904), mostrando a importância do endosso à literatura de autoria feminina por parte de um escritor renomado. Tais articulações não são gratuitas, e, por meio delas, entendemos os mecanismos sociais de inserção e de exclusão, de permanência e de esquecimento, das escritoras no meio literário. Por mais que escritoras como Narcisa Amália, Albertina Bertha e Júlia Lopes de Almeida tenham conquistado espaço privilegiado para expressar e divulgar sua produção literária e ultrapassado o domínio privado para transitar no domínio público, elas continuavam 


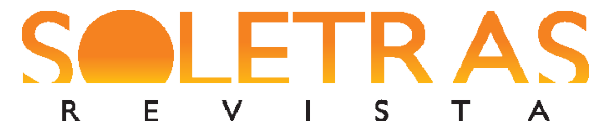

sujeitas à autoridade e ao monopólio do reconhecimento circunscritos ao gênero masculino. Prova disto talvez seja o apagamento das escritoras na história da literatura. Se por um lado, os arquivos comprovam que as mulheres participaram ativamente da vida cultural e literária; por outro lado, é possível constatar que tal inserção não foi efetiva para lhes assegurar registros permanentes no cânone e na tradição literária brasileira.

$\mathrm{O}$ ato $\ddot{i}$ tido como generoso $\ddot{i}$ de ceder espaço para a expressão feminina, isto é, autorizar a sua entrada em um universo restrito, cujo domínio é masculino, além de amenizar a percepção da violência do silenciamento, é perigoso por criar uma ilusão de pertencimento. Sendo assim, as mulheres participaram da vida cultural e intelectual na transição do século XIX ao XX, porém, sob controle dos detentores do poder. Estavam sempre à mercê da liberalidade masculina, para que fossem autorizadas a ingressar e a ter voz no meio literário. Os homens é que ocupavam os espaços de poder. Os homens eram os editores, que decidiam as obras a serem publicadas; os formadores de opinião e críticos literários, que avaliavam o valor das obras, os diretores dos grandes jornais, os membros da Academia Brasileira de Letras etc. Ï, são eles quem decidem os instrumentos de medição para o que é superior na literatura.Vale lembrar o caso de Júlia Lopes de Almeida, integrante do grupo de intelectuais que planejava a construção da ABL em 1897. Seu nome constava na lista dos ñ 0 imortaisò, porém foi deliberadamente excluída da $\mathrm{ABL}$, pois seus fundadores optaram por uma academia exclusivamente masculina tal qual a Académie Française. Em seu lugar, entrou o poeta português Filinto de Almeida, marido de Júlia Lopes de Almeida. Em entrevista a João do Rio, Filinto demonstra sua inconformidade com a decisão, afirmando: ñNão era eu quem deveria estar na Academia, era elaò.

Não é raro o apadrinhamento das escritoras, assim como não é incomum oprefácio escrito por um homem avalizando a literatura de autoria feminina, ou seja, ñautorizandoò seu ingresso no mundo masculino das nossas letras. No caso de Albertina Bertha, o padrinho foi Araripe Júnior, que recomendou (com êxito) a publicação de Exaltação no Jornal do Commercio. Araripe Jr., por sua vez, era muito amigo do pai de Albertina, o renomado e prestigiado jurista Conselheiro Lafayette. No caso de Narcisa Amália, a estratégia de inserção fica evidente a partir da recomendação nada sutil que Póvoa faz da poeta ao seu círculo de relações:

Eu peço que julguem o livro de N. Amália, livro que ilumina a grande noite da poesia brasileira. Quando houver um Conselho de Estado ou um Senado Literário, Narcisa Amália terá as honras de Princesa das letras. [é ] Teófilo 


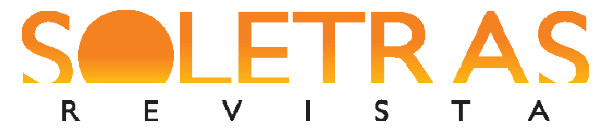

Braga, Luciano Cordeiro, Cesar Machado, Adolfo Coelho, Bulhão Pato, Gomes Leal, E. Coelho, Silva Túlio, A. de Castilho, Silva Pinto e Teixeira Vasconcelos, meus amigos, hão de deferir o seguinte requerimento: Peço um lugar de honra no auditório das vossas glórias literárias para a autora das Nebulosas (PÓVOA, 2017, p. 28).

Em seu importante estudo, Eleutério (2005) analisa o ingresso das escritoras no círculo das letras a partir da presença de um homem ï pai, irmão, marido, padrinho ï que articula e autoriza a sua entrada na ñchamada República das Letrasò. ñuma hereditariedade muito comum ao patrocínio do fazer literárioò (ELEUTÉRIO, 2005, p. 19). Trata-se de um trabalho primoroso sobre 18 escritoras brasileiras, entre elas Amélia de Oliveira, Josefina Álvares de Azevedo, Júlia Lopes de Almeida, Narcisa Amália, Albertina Bertha, Carmem Dolores etc. e o modo como elas conseguiram alguma entrada neste espaço interdito através das relações de parentesco ou de apadrinhamento. Apesar de Eleutério afirmar que Narcisa não tinha ñirmãos ou parentes que pudessem iniciá-la no mundo das letras através de salõesò e esta seria uma ñıma razão plausível para sua fugaz permanência no ambiente das letrasò (ELEUTÉRIO, 2005, p. 117), acreditamos que haja elementos que permitem uma interpretação diversa. Segundo a linha de raciocínio da socióloga, podemos dizer que o homem que abriu as portas do mundo das Letras para Narcisa Amália foi seu pai, Joaquim Jácome de Oliveira Campos Filho, mais conhecido como professor Jácome de Campos.

Narcisa cresceu em meio a muita cultura, mesmo tendo vivido sem muitos recursos materiais. Seu pai era educador, poeta e jornalista, um homem de vasta cultura, que colaborou nos diversos jornais da imprensa fluminense e paulista, além de ser co-fundador e redator de O Paraybano (1859-1870), primeiro jornal editado em São João da Barra. Colaborou com o Astro Resendense e Pirilampo. Em janeiro de 1874, ele e outros jornalistas fundaram o jornal Resendense. A influência do pai de Narcisa Amália era notável e contribuiu para o lançamento da filha. O renomado escritor e jornalista Pessanha Póvoa, prefaciador da primeira edição de Nebulosas, era ex-aluno e admirador de Jácome Campos. Também o contato do pai com amigos jornalistas abriu as portas para que Narcisa pudesse publicar nos jornais locais e ser considerada a primeira jornalista brasileira. Entre os jornais com os quais colaborou, estão Astro Resendense, Monitor Campista, Echo Americano, O Espírito Santense, Gazeta de Campos, Correio Fluminense, Tymburibá, A República, Correio do Povo, O Fluminense etc.

De acordo com Fonseca, 
[...] a família conquistou o respeito de toda a sociedade e, em todas as atividades sociais, a presença do casal era imprescindível. Foram tantas as atividades do prof. Jácome que o Imperador D. Pedro II, em visita a Resende, em 16/10/1874, homenageou-lhe com a comenda da Ordem do Cristo, distinção imperial conferida aos mestres dedicados (FONSECA, 2008, p. 11).

A mãe, Narcisa Ignácia Pereira de Mendonça, também era professora e teve papel fundamental na educação da filha. Narcisa foi alfabetizada pelos pais aos quatro anos de idade. O registro de Luiz Francisco de Veiga mostra-nos a educação privilegiada da poeta fluminense:

Aos seis anos, já sabendo ler corretamente, entrou para o colégio de D. Maria da Costa Brito e Azevedo, a fim de continuar o encetado estudo da gramática portuguesa e também para estar presa a um regime disciplinar, menos amoroso e indulgente do que a casa paterna, visto ser excessivamente travessa. Aos oito anos, começou seu estudo de música (arte que tem sempre cultivado) retirando-se do colégio aos dez anos, obtendo distinção em todos os seus exames (VEIGA apud FONSECA, 2008, p. 7).

Ademais, estudou latim e francês, ainda em São João da Barra, com o padre Joaquim Francisco da Cruz Paula, e recebeu aulas de retórica de seu pai. Em Resende, no ano de 1865, com apoio do presidente da Câmara Municipal, Dr. João de Azevedo Carneiro Maia, seus pais criaram dois colégios, o Colégio Jácome para meninos e o Colégio Nossa Senhora da Conceição para meninas, que recebiam alunos do município e cidades vizinhas (FONSECA, 2008). Desde os 13 anos, Narcisa auxiliava a mãe nos afazeres do ensino superior, ministrando às jovens do internato conhecimentos de cultural geral. Havia um ambiente favorável ao aprendizado, à cultura, ao interesse por línguas, à escrita, à iniciação no mundo das letras, que fizeram de Narcisa Amália uma mulher-escritora diferenciada em sua época. 


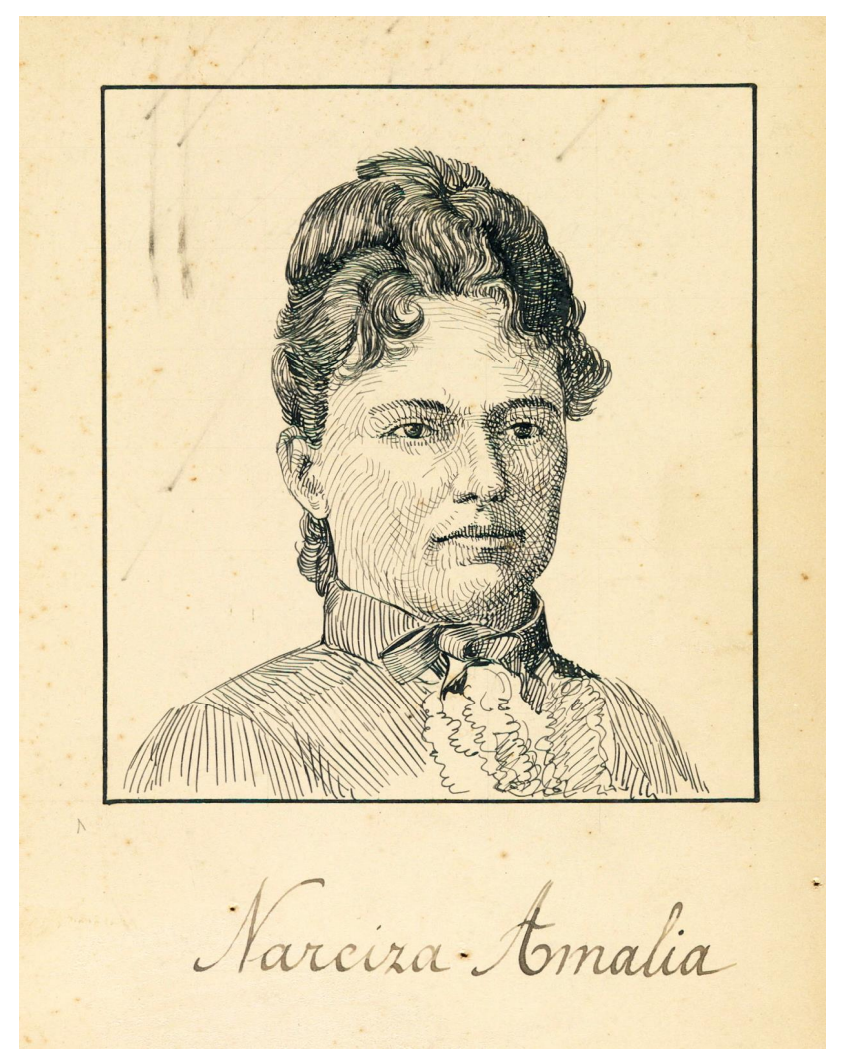

Fig. 2: Narcisa Amália aos 50 anos de idade, por M. J. Garnier. ${ }^{7}$

\section{Repercussão e intempéries da trajetória literária feminina}

Em prefácio entusiasmado, Póvoa atribuiu pioneirismo à Narcisa Amália:

Narcisa Amália será a impulsora e o ornamento de uma época literária mais auspiciosa que a presente. Há de redigir os aforismos poéticos, como Aristóteles escreveu os da natureza. [é ] Narcisa Amália não é um tipo, é uma heroína. [...]Este livro há de produzir tristezas e alegrias. É a primeira brasileira dos nossos dias; a mais ilustrada que nós conhecemos; é a primeira poetisa desta nação. Delfina da Cunha, Floresta Brasileira, Ermelinda da Cunha Matos, Maria de Carvalho, Beatriz Brandão, Maria Silvana, Violante, são bonitos talentos. Narcisa Amália é um talento feio, horrível, cruel, porque mata àqueles. Foram as suas antecessoras auroras efêmeras; ela é um astro com órbita determinada (PÓVOA, 2017, p. 22. Grifo meu).

Póvoa lamenta o estado atual da poesia e vê em Narcisa a esperança para a literatura contemporânea brasileira. É inegável que a recomendação por parte do prefaciador tenha influenciado na recepção crítica de Nebulosas. Infelizmente, quando se trata de literatura de autoria feminina, não é apenas o valor literário que está em jogo, mas as formas de inserção

\footnotetext{
${ }^{7}$ Disponível em http://bndigital.bn.br/acervodigital. Acesso em: 15 ago. 2017.
} 
desta produção em um meio que é restrito aos homens e as relações interpessoais. Uma vez lançada, a obra de Narcisa Amália foi aclamada pelos leitores, recebendo muitos prêmios e comentários elogiosos na imprensa periódica.

Em 1873, a laureada autora de Nebulosas recebeu o prêmio ñira de ouroò, com direto a festa, discursos e troféus. Ubiratan Machado registra com maior riqueza de detalhes a homenagem recebida por Narcisa Amália:

Entusiasmados, os conterrâneos ofereceram à poetisa uma festa sem similar na história do romantismo brasileiro. A preparação foi minuciosa, criaram-se comissões incumbidas de organizar a subscrição popular, destinada a recolher uma importância suficiente para homenagear Narcisa com uma lembrança inesquecível. No dia 2 de março de 1873, no salão de honra da Câmara Municipal de Resende, feericamente iluminado e cheio de flores, reuniam-se mais de trezentos convidados, entre damas e cavalheiros. Às nove horas, uma salva de 21 tiros anuncia a chegada de Narcisa Amália. Conduzida ao salão nobre, recebe aplausos quase tão barulhentos quanto os tiros de canhão. Duas meninas lhe oferecem uma lira de outro, uma coroa de louros e uma pena de ouro (MACHADO, 2001, p. 261).

Em setembro de 1874, Narcisa recebeu o prêmio da Mocidade Acadêmica, uma pena de ouro entregue pelas mãos do conselheiro Saldanha Marinho:

Exma. Sra. D. Narcisa Amália ï Recebi, da esperançosa mocidade acadêmica do Rio de Janeiro, o gratíssimo encargo de depor, nas mãos de V. Ex., a pena de ouro, que ora tenho a honra de lhe entregar. Este mimo, na sua mais elevada significação, exprime, da parte dos generosos mancebos, que hão de ser um dia glórias da nossa pátria querida, o testemunho da admiração e respeito que lhe votam os laureados talentos da distintíssima autora das Nebulosas, aqueles alvos cisnes do mar da imensidade(MARINHO, 1874, p. 2).

A resposta de Narcisa ao discurso de Marinho e à homenagem recebida é digna de nota. Sob forma de protesto, a poeta aproveita o espaço de escuta para fazer seu discurso feminista em prol da liberdade feminina, revelando muitas das intempéries da trajetória das mulheres, entre elas: a condição de escrava do homem; quando transgressora, é alvo de preconceitos; fadada às trevas e à ignorância de seus direitos; desencorajada por um sistema machista e autoritário etc. Ela mesma se reconhece como uma voz dissonante à época, rebelde porque incentivada pelos pais, que não se sujeitou, saindo das trevas e enfrentando os preconceitos típicos contra qualquer mulher que ousa transgredir a dominação masculina:

Preclaro cidadão $\ddot{~}$ Vós que sois o intérprete dos sentimentos da briosa mocidade acadêmica, vós que vindes falar-me em seu nome e oferecer-me este símbolo da força, esta alavanca do pensamento, este gladio iriante das 
ideias, dignai-vos a aceitar, nestas desalinhadas palavras, o protesto mais veemente do meu reconhecimento para transmiti-lo a eles ï que são a mais lisonjeira esperança da pátria. [...] A humanidade, contingente pelo vício da sua própria natureza, não pode aproximar-se de seu Criador senão amparada pela liberdade; livre o pensamento é necessário que livres sejam os movimentos que devem executá-lo: o código que o dirige está escrito no seu próprio coração e, uma vez compreendido, a tirania é um crime, a sujeição uma violência, as quais só podem submeter-se a fraqueza e a ignorância.

Voltai os olhos e vereis: ï a mulher é a escrava do homem, e, se quebra os elos que a jungem ao poste, fica ainda escrava dos preconceitos. Conservaram-na em trevas para que desconheça o seu direito, e quando rompe a nuvem espessa que segrega-a das lucubrações elevadas, quando quer aspirar o ambiente vivificante das regiões superiores, vem o motejo e a irrisão precipitá-la no abismo de onde nunca deveria ter saído.

Pois bem: eu reneguei a escravidão porque deixaram-me compreender que Deus me fizera livre como a emanação das flores que recamam os campos; livre como a brisa que doudeja pelo espaço: não escutei o motejo dos néscios, nem ouvi o gargalhar satânico dos incrédulos; olhei para o futuro, escrevi o que pensava, o que me havia ensinado a lição caída dos lábios paternos, e deixei que esses pobres pensamentos fossem peregrinar pelo mundo (AMÁLIA, 1874, p. 2.Grifos meus).

Considerada uma das primeiras feministas no Brasil, enxergava com lucidez a condição da mulher no século XIX. Em 31 de dezembro de 1886, em carta publicada em $A$ Família, Narcisa afirma: ñSuponho ter sido eu, no Brasil, quem primeiro ergueu a voz clamante contra o estado de ignorância e de abatimento em que jazíamosò (AMÁLIA, 1886, apud OSCAR, 1994, p. 63).

No artigo ñA mulher do século XIXò, Narcisa relacionou a inteligência feminina a uma espécie de ñarmas para o malò. O olhar crítico da poeta lhe dava pleno discernimento da ñprofunda separação intelectual e moralò entre homens e mulheres:

ñA educação da mulher! Mas tem a mulher por acaso necessidade de ser educada? Para quê? Cautela! A mulher representa o gênio do mal sob uma forma mais ou menos graciosa e cultivar a sua inteligência seria fornecerlhe novas armas para o mal. Procuremos antes torná-la inofensiva por meio da ignorância. Guerra, pois, à inteligência feminil!ò

Eis a palavra do século passado. [...]

Nada há que justifique essa tenaz perseguição da mulher; e entretanto foi perpetuada de século a século!

A mulher no século dezenove acha-se, portanto, emancipada, isto é, entra na posse de si mesma, conquista o direito divino de sua alma, em uma palavra, transfigura-se. O que lhe falta ainda para ser feliz? ï À que está emancipada, pouco; mas à que está por emancipar-se, tudo. E neste caso está a mulher brasileira. Entre nós a instrução, mesmo a mais elementar, tem até aqui constituído monopólio do homem. Ora, à medida que o homem sobe, a 


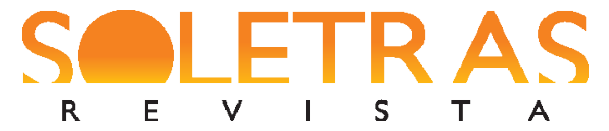

mulher desce, naturalmente, e essa diferença cria entre ambos uma profunda separação intelectual e moral que arrasta consigo todas as desordens do lar (AMÁLIA apud RAMALHO, 1999, p. 129. Grifo meu).

A angústia de Narcisa Amália em relação à iniquidade de gênero se revela por meio de suas cartas. Ao amigo Alfredo Sodré, lamenta a dificuldade de uma mulher se revelar artista e inteligente face ao meio desfavorável em que vive. ${ }^{8}$ Como bem observa Norma Telles (2013), a mulher aprendia a ser inepta, incorporando o discurso do dominante e se adequando ao padrão estabelecido e esperado. A observação de Telles ecoa a de Narcisa, para quem a mulher se habitua ñao balbucio de insignificantes frases convencionaisò. Ademais, a metáfora sufocante de uma mulher enclausurada que se debate em vão e vê sua inteligência ser arruinada é extremamente ilustrativa do tormento que vive uma mulher consciente de sua condição:

[é ] como há de a mulher revelar-se artista se os preconceitos sociais exigem que o seu coração cedo perca a probidade, habituando-se ao balbucio de insignificantes frases convencionais? Vitimada pela opressão, galé do círculo murado em que inutilmente se debate, a mulher inteligente acompanha com mágoa a extinção gradativa de sua fecundidade cerebral, seguindo com olhos rasos de pranto a inspiração que ala-se para sempre, movendo em largo vôo sereno as asas flamejantes, menos feliz que a pomba da tradição bíblica, sem ter encontrado um ramo de loureiro onde por instante repousasseé (AMÁLIA, 1898, apud REIS, 1949, p. 103).

Em carta de 1873 a José Palmela, Narcisa Amália lamenta por as mulheres não poderem cursar Academias, demonstrando certa inferioridade ao se comparar com Palmela: ñNão tem esses ligeiros trabalhos o mérito de vossas produções, mas encerram como elas as primícias de uma alma de moça que não pôde cursar Academias, ainda entre nós cerradas às santas aspirações da inteligência femininaò (AMÁLIA, 1873, apud OSCAR, 1994, p. 64). O tom é similar ao de Maria Firmina dos Reis (1825-1917) no prólogo do romance Úrsula(1859), considerado o primeiro romance escrito por uma mulher negra no Brasil e publicado sob o pseudônimo de ñUma maranhenseò.

Machado de Assis, em sua crônica elogiosa a respeito de Nebulosas (1872), comenta que

Há, sem dúvida, alguma página menos aperfeiçoada, algum verso menos harmonioso, alguma imagem menos própria; mas, além de que esses senões melhor os conhecerá e me dará a autora com o tempo (e um talento verdadeiro não deixa de os conhecer e emendar), é antes de admirar que o

\footnotetext{
${ }^{8}$ Carta a Alfredo Sodré publicada nôO Guaratuja, 19 abr. 1898. 


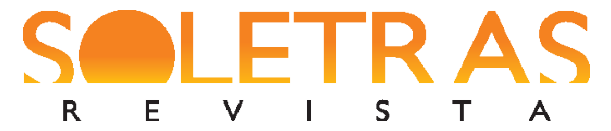

seu livro não saísse menos puro, dadas as condições de uma estreia (MACHADO DE ASSIS, 1872, s/p).

Infelizmente, Narcisa Amália não publicou mais e, com isso, não pudemos acompanhar esse ñalento verdadeiroò após a ñcondição de estreiaò. As intempéries da sua trajetória intelectual e pessoal não foram poucas. Sofreu preconceito por ter sido casada duas vezes e ter se separado dos dois maridos, por ser inteligente e bonita $і ̈$ par de adjetivos interdito ï, por ser escritora, jornalista profissional, feminista e independente. Teve a autoria de seus poemas posta em xeque, provavelmente pelo ex-marido desprezado (OSCAR, 1994, p. 71-72). Mesmo tendo notável recepção de seu livro, recebendo o consagrado prêmio ñira de ouroòe a ñpena de ouroò da Mocidade Acadêmica, entre outras homenagens, sendo admirada pelo Imperador D. Pedro II, pelo escritor Machado de Assis e outros poetas importantes, Narcisa Amália é mais um, entre tantos, exemplo de mulheres vítimas de um apagamento injusto.

\section{Referências}

AMÁliA, Narcisa. Nebulosas. Apresentação e posfácio de Anna Faedrich. 2. ed. Rio de Janeiro: Gradiva Editorial; Fundação Biblioteca Nacional, 2017.

AMÁliA, Narcisa. Diário de Rio de Janeiro, Rio de Janeiro, p. 2, 28 set. 1874.

ARAÚJO, Gilberto. Gilka Machado: corpo, verso e prosa. Conferência proferida na ABL. In: Revista Brasileira, v. 80, 2014, p. 115-128. Disponível em: http://www.academia.org.br/abl/media/RB80\%20-

\%20A\%20LITERATURA\%20DE\%20AUTORIA\%20FEMININA.pdf. Acesso em 15 ago. 2017.

ELEUTÉRIO, Maria de Lourdes. Vidas de romance: as mulheres e o exercício de ler e escrever no entresséculos (1890-1930). Rio de Janeiro: Topbooks, 2005.

FONSECA, Yara Vidal. Narcisa Amália, 150 anos de nascimento. Trabalho apresentado na Academia Niteroiense de Letras em 10 de abril e 2002. 2. ed. Rio de Janeiro: N\&S Encadernadora, 2008.

MACHADO DE ASSIS, Joaquim Maria. ñNebulosasò. Semana Illustrada, n. 629, 29 dez. 1872.

MACHADO, Ubiratan. A vida literária no Brasil durante o romantismo. Rio de Janeiro: EdUERJ, 2001.

MARINHO, J. Saldanha. Diário de Rio de Janeiro, Rio de Janeiro, p. 2, 28 set 1874. 
OSCAR, João. Narcisa Amália. Vida e poesia. Campos: Lar Cristão, 1994.

PAIXÃO, Sylvia Perlingeiro. Narcisa Amália. In: MUZART, Zahidé Lupinacci (Org.). Escritoras brasileiras do século XIX. 2. ed. rev. Florianópolis: Editora Mulheres; Santa Cruz do Sul: EDUNISC, 2000, p. 534-552.

PÓVOA, Pessanha. Prefácio. In: AMÁLIA, Narcisa. Nebulosas. Apresentação e posfácio de Anna Faedrich. 2. ed. Rio de Janeiro: Gradiva Editorial; Fundação Biblioteca Nacional, 2017, p. $15-28$.

RAMALHO, Christina. Um espelho para Narcisa. Reflexos de uma voz romântica. Rio de Janeiro: Elo, 1999.

REIS, Antônio Simões dos. Narcisa Amália. Rio de Janeiro: Organizações Simões, 1949.

TELLES, Norma. Escritoras, escritas, escrituras. In: DEL PRIORE, Mary (Org.). História das mulheres no Brasil. São Paulo: Contexto, 2013, p. 401-442.

\section{Narcisa Amália, forgotten poet of the $19^{\text {th }}$ century}

Abstract: I analyze the importance of the poetic production of Narcisa Amália (1852-1924) in the Brazilian literary scenario of the nineteenth century and the mechanisms of exclusion of Brazilian writers from our literary records. We ignore the literature of female authorship of the nineteenth century, not for lack of women writers or publications, but for their deliberate dumping of literary history. The world of our letters is predominantly masculine. I intend to show how Narcisa Amália has gained space in this universe restricted to men, her awareness of the oppression suffered by being a woman and the critical reception of her work.

Keywords: Narcisa Amália. Nebulosas. History of Brazilian Literature. Literary Criticism. $19^{\text {th }}$ century.

Recebido em: 09 de outubro de 2017.

Aprovado em: 26 de outubro de 2017. 